\title{
POSITIVE IMPACT OF SPEECH THERAPY IN PROGRESSIVE NON-FLUENT APHASIA
}

\author{
Paola Andrade-Calderón ${ }^{* 1,2}$, Judith Salvador-Cruz ${ }^{* 1}$, Ana Luisa Sosa-Ortiz ${ }^{* 2}$ \\ ${ }^{1}$ Zaragoza School of Advanced Studies, National Autonomous University of Mexico, Mexico City, Mexico \\ ${ }^{2}$ Laboratory of Dementia, National Institute of Neurology and Neurosurgery "Manuel Velasco Suárez". Mexico City, Mexico
}

Recibido, abril 21/2014

Concepto de evaluación, mayo 9/2014

Aceptado, junio 15/2014
Referencia: Andrade-Calderón, P., Salvador-Cruz, J. \& Sosa-Ortiz, A.L. (2015). Positive impact of speech therapy in progressive non-fluent aphasia. Acta Colombiana de Psicología, 18 (2), 101114. DOI: 10.14718/ACP.2015.18.2.9

\begin{abstract}
The aim of this paper is to analyze the effects of intensive speech therapy intervention in a case of progressive non-fluent aphasia (PNFA). This is a dementia syndrome characterized by a progressive deficit in expressive language fluency and syntactic analysis, and by agrammatism and phonemic paraphasias. Although in the early stages there are no alterations in memory, comprehension, or visual processing, personality changes can slightly occur. To analyze the effects of speech therapy in this syndrome, a single case design with pre- and post-test was used. The participant was a male patient of 84 years with PNFA, who for twelve months received weekly speech therapy to stimulate the phonological, lexical and syntactic processing. He underwent neuropsychological assessment in three stages: six months before the onset of therapy, six months after therapy started and after completing 12 months of intervention. Assessment involved linguistic processing, general cognition, neuropsychiatric symptoms, quality of life (QOL) and activities of daily living (ADL). As a result of therapy, the patient showed a slight improvement in language prosody, fluency, and content of spontaneous speech, and a significant improvement in repetition, reading aloud, and oral-phonatory praxis. Other aspects of cognitive functioning (orientation, verbal naming, praxis, and memory) remained stable; ADLs and QOL improved. It is concluded that prolonged speech therapy can improve language processing and have a positive impact on other cognitive and socio-emotional processes in PNFA. This 12-month therapeutic stimulation not only slowed cognitive decline, but allowed to see maintenance of achievements and improvement of symptoms, which can be regarded as a success in PNFA treatment, considering the rapid progression of the disease.

Key words: progressive non-fluent aphasia, speech therapy, frontotemporal dementia, primary progressive aphasia.
\end{abstract}

\section{IMPACTO POSITIVO DE LA TERAPIA DEL LENGUAJE EN AFASIA PROGRESIVA NO FLUENTE}

\author{
Resumen
}

\begin{abstract}
El objetivo de este artículo es analizar los efectos de una intervención intensiva de terapia del lenguaje en un caso de afasia progresiva no fluente (APNF). Este es un síndrome demencial caracterizado por un déficit progresivo en la fluidez del lenguaje expresivo y el análisis sintáctico, y por agramatismo y parafasias fonémicas. Aunque en las primeras etapas no presenta alteraciones en la memoria, la comprensión o el procesamiento visual, sí pueden presentarse ligeros cambios en la personalidad. Para analizar los efectos de la terapia del lenguaje en este síndrome, se utilizó un diseño de caso único con pre y post prueba. El participante fue un paciente masculino de 84 años con APNF, quien durante doce meses recibió una terapia de lenguaje semanal para estimular el procesamiento fonológico, léxico y sintáctico. Se le realizó una evaluación neuropsicológica en tres etapas: seis meses antes del inicio de la terapia, después de seis meses de intervención, y al completar 12 meses de esta. Específicamente se evaluó el procesamiento lingüístico, la cognición general, los síntomas neuropsiquiátricos, la calidad de vida $(\mathrm{CdV})$ y las actividades de la vida diaria (AVD). Como resultado de la terapia, el paciente mostró ligeras mejorías en la prosodia, la fluidez y el contenido del lenguaje espontáneo, y una mejoría significativa en la repetición, la lectura en voz alta y las praxias orofonatorias. Otros aspectos cognitivos (orientación, denominación verbal, praxias y memoria) se mantuvieron estables; las AVD y la CDV mejoraron. Se concluye que la terapia del lenguaje prolongada puede mejorar el procesamiento lingüístico y también tener un impacto positivo en otros procesos cognitivos y socio-emocionales en la APNF. La intervención
\end{abstract}

\footnotetext{
* Posgrado e Investigación. FES-Zaragoza UNAM. Batalla 5 de Mayo S/N, esquina Fuerte de Loreto, Col. Ejército de Oriente, CP. 09230, D.F, México .Tel:+52 5556230701.

** Av. Insurgentes Sur No. 3877, Col. La Fama, Del. Tlalpan, C.P. 14269, D.F., México.

PAAC: paolandrade@hotmail.com, JSC: salvadcj@gmail.com
} 
no solo disminuyó la velocidad del deterioro cognitivo, sino que permitió ver el mantenimiento de los logros y la mejoría de los síntomas, lo cual es un éxito en el tratamiento de la APNF, debido a su rápida progresión

Palabras clave: afasia progresiva no fluente; terapia del habla, demencia frontotemporal, afasia progresiva primaria.

\title{
IMPACTO POSITIVO DA TERAPIA DA LINGUAGEM EM AFASIA PROGRESSIVA NÂO FLUENTE
}

\author{
Resumo
}

\begin{abstract}
O objetivo deste artigo é analisar os efeitos de uma intervenção intensiva de terapia da linguagem em um caso de afasia progressiva não fluente (APNF). Esta é uma síndrome demencial caracterizada por um déficit progressivo na fluência da linguagem expressiva e da análise sintática, e por agramatismo e parafasias fonêmicas. Ainda que nas primeiras etapas não presenta alterações na memória, na compreensão ou no processamento visual, podem aparecer pequenas mudanças na personalidade. Para analisar os efeitos da terapia da linguagem nesta síndrome, utilizou-se um desenho de caso único com testes antes e depois. O participante foi um paciente masculino de 84 anos com APNF, que durante doze meses recebeu uma terapia de linguagem semanal para estimular o processamento fonológico, léxico e sintático. Realizou-se uma avaliação neuropsicológica em três etapas: seis meses antes do início da terapia, depois de seis meses de intervenção, e ao completar 12 meses desta. Avaliou-se especificamente o processamento linguístico, a cognição geral, os sintomas neuropsiquiátricos, a qualidade de vida (QdV) e as atividades da vida diária (AVD). Como resultado da terapia, o paciente mostrou pequenas melhorias na prosódia, na fluência e no conteúdo da linguagem espontânea, e uma melhoria significativa na repetição, na leitura em voz alta e nas praxias orofonatórias. Outros aspectos cognitivos (orientação, denominação verbal, praxias e memória) mantiveram-se estáveis; as AVD e a QdV melhoraram. Conclui-se que a terapia da linguagem prolongada pode melhorar o processamento linguístico e também ter um impacto positivo em outros processos cognitivos e sócio emocionais na APNF. A intervenção diminuiu não somente a velocidade da deterioração cognitiva, senão que permitiu ver a manutenção dos êxitos e a melhoria dos sintomas, o que representa um sucesso no tratamento da APNF, devido a sua rápida progressão

Palavras chave: afasia progressiva não fluente; terapia da fala, demência fronto temporal, afasia progressiva primária.
\end{abstract}

\section{INTRODUCTION}

Frontotemporal dementia (FTD) is a group of clinical syndromes associated with the degeneration of frontal and anterior temporal cortical regions (Neary et al., 1998). Primary progressive aphasia (PPA), a subtype of FTD, is characterized by different patterns of language impairment distinguished by three clinical phenotypes: semantic, logopenic, and non-fluent/agrammatic variants. Patients with the semantic variant show abnormalities in single word comprehension and naming, with relatively preserved grammar and fluency; patients with the logopenic variant have intermittent word-finding hesitations, phonemic paraphasias, and impaired repetition (Gorno-Tempini et al., 2011). The non-fluent/agrammatic variant, also known as progressive non-fluent aphasia (PNFA) is characterized by a progressive deficit in expressive language fluency, agrammatism, and phonemic paraphasias. Although in the early stages there are no alterations in memory, comprehension, or visual processing, slight personality changes can occur; there is a deficit of syntactic analysis at the onset of illness (Mesulam et al., 2003).

The speech feature referred to as speech apraxia is an impairment in the motor planning and sequencing of the movements, which leads to stuttering over the initial con- sonant of a word, hesitation in mid-word, and a breakdown of normal speech rhythm (Gorno-Tempini et al., 2004). In PNFA, the grammar used is often simplified, with occasional inflectional errors (Clark et al., 2005; Graham et al., 2004; Wang et al., 2005). Although having clinically normal episodic memory, affected patients show poor execution on verbal memory tests (Neary et al., 1998; Hodges et al., 1999; Graham et al., 2003). For such patients, visuo-spacial abilities are well preserved (Graham et al., 2003; Perry \& Hodges, 2000), but executive functions are usually impaired, especially in sorting and digit-span tasks (Hodges et al., 2000; Nestor et al., 2003). The diagnosis of PNFA is usually made when other cognitive processes are found to be relatively preserved, with language being the only impaired area, at least during the first two years of the disease (Mesulam, 2003). As the illness advances, oral expression is reduced and comprehension is progressively altered. There is significant decline in the number and length of words produced; patients eventually become monosyllabic, communicate only with unintelligible grunts, and in advanced stages, may become mute (Gorno-Tempini et al., 2004).

Neuroimaging studies of PNFA patients (Nestor et al., 2003) have shown atrophy in the left posterior area of the frontal lobe, a region associated with speech production 
and the coordination and planning of articulation movements. The alterations were thought to be localized in the left hemisphere, mainly in the pars opercularis of the inferior frontal gyrus (Brodmann area (BA) 44), upper temporal pole (BA 38), basal ganglia (lenticular nucleus), and middle frontal gyrus (BA 8/9) (Friederici \& Kotz, 2003). In advanced cases in which mutism occurs, the alterations were found to extend into subcortical regions (Gorno-Tempini et al., 2006, Neary et al., 1998). Fluency deficits have usually been associated with atrophy in the posterior inferior and middle frontal gyrus, whereas grammatical processing is associated with more widespread atrophy, including other regions of the inferior frontal gyrus and supramarginal gyrus (Rogalski et al., 2011).

Unlike people with Alzheimer Disease (AD), patients with PNFA often become aware of the problem earlier than family members or other people close to them do, with difficulties arising in linguistic demanding situations. Such patients do not usually complain of memory disturbances other than in the verbal domain; they are not disorientated and their activities of daily living (ADLs) typically remain unaffected; significant personality changes may occur in advanced stages of the disease (Gorno-Tempini et al., 2004; Neary et al., 1998).

This type of aphasia is caused by a neurodegenerative disease that is second only to AD in prevalence and which accounts for $10-15 \%$ of untreatable dementias (Boeve, 2003), It is considered a dementia not only due to the gradual cognitive impairment that compromises the development of the patient's ADLs related to communication, but also due to additional manifestations, such as depressive symptoms, which may occur in reaction to these deficits, affected ADLs, or the shame and frustration caused by the inability to communicate and interact, which can lead to social deterioration (Raymer et al., 2001). From reports on prognosis in PNFA (Rogers \& Alarcon, 1999; Hodges et al., 2003), the median survival is 6.8 years; therefore, a rapid progression of the disease is expected.

\section{Intervention experience}

It is known that patients with PNFA may benefit from language stimulation, such as that provided by the strategies used in non-progressive language disorders (Berndt, Mitchum \& Haendiges, 1996; Greenwald et al., 1995; Kiran \& Thompson, 2002; Raymer \& Ellsworth, 2002). To date, most treatments have been implemented with the aim of improving naming, a deficit that is the characteristic symptom in the early stages. Researchers have used both visual stimulus (Laurence et al., 2002;
Rapp \& Glucroft, 2009) and computerized approaches (Jokel et al., 2009) to stimulate the specific naming of objects, both orally and in writing. Others have focused on retrieval of nouns, adjectives, and verbs by improving the knowledge of semantic attributes through gesture (Schneider, Thompson \& Luhring, 1996) or by stimulating auditory-phonological processing (Koenig-Bruhin et al., 2005; Louis et al., 2001).

Farrajota et al. (2012) reported that, through a combination of different exercises (such as picture naming, describing actions depicted in pictures, comprehending complex auditory-verbal exercises, reading and writing, facilitating expression of feelings and opinions, and enhancing conversational skills), speech and language therapy can improve naming ability and verbal fluency for patients with PNFA. By combining behavioral and pharmacological treatment (dextroamphetamine, a psychostimulant and amphetamine stereoisomer), McNeil et al. (1995) assessed the efficacy of an intervention for a person with PPA (specifically to treat dysnomia). They found that the improvement in performance and word-finding ability was more evident when the patient had received both treatments, thus highlighting the importance of having a combined pharmacological and non-pharmacological treatment for an efficient intervention.

Other studies applying behavioral treatment reported that, immediately after treatment, improvements were seen in worked material (Farrajota et al., 2012; Jokel et al., 2009; Koenig-Bruhin et al., 2005; Laurence et al., 2002; Louis et al., 2001; McNeil et al., 1995; Rapp \& Glucroft, 2009; Schneider et al., 1996) and in generalization (Louis et al., 2001; McNeil et al., 1995; Schneider et al., 1996). In these studies, the intervention period was two weeks to one month (Laurence et al., 2002), one to three months (Jokel et al., 2009; Laurence et al., 2002; Louis et al., 2001; Rapp $\&$ Glucroft, 2009), or five to eleven months (Farrajota et al., 2012; Koenig-Bruhin et al., 2005; McNeil et al., 1995; Schneider et al., 1996). It was found that, without practice nor intervention, the benefits disappeared after one month (Jokel et al., 2009), three months (McNeil et al., 1995; Schneider et al., 1996), or six months (Laurence et al., 2002; Rapp \& Glucroft, 2009). The patients treated in these studies were in mild-to-moderate stages of impairment. Because most of the studies published were focused on stimulating a single linguistic process (i.e., naming) (Jokel et al., 2009; Koenig-Bruhin et al., 2005; Laurence et al., 2002; Louis et al., 2001; McNeil et al., 1995; Rapp \& Glucroft, 2009; Schneider et al., 1996), this may be the reason for the positive results in improving naming, with little or no generalization, improvement, or maintenance 
after intervention of unworked material (Koenig-Bruhin et al., 2005). This is an important limitation of the intervention design that was used in these studies.

The presence and progression of all the changes in cognition and behavior in a patient affect the patient's family environment. Because caregivers have to understand, cope with and accept the symptoms (Raymer et al., 2001) this can become a critical problem. Caregivers of dementia patients often experience high levels of stress, overload, anxiety, and other negative impacts on both the emotional and physical levels (Riedijk, et al., 2006; Mioshi et al., 2009).

Evidence from these studies suggests that properly designed interventions may have positive effects on language functioning; however, there are some limitations - in particular, the duration of intervention, as little is known about whether a patient receiving speech therapy for more than six months can maintain and/or improve language performance. It is also unknown if speech therapy can have a positive effect on other non-linguistic aspects, such as general cognition, quality of life (QOL), ADLs, mood, and family environment.

The characteristics of the aforementioned interventions show the need for and importance of the design, implementation, and dissemination of systematic speech therapy programs for PNFA patients, that are not only ecologically valid and can be replicated, but that can also be used to assess the benefit, maintenance, and/or generalization of the intervention. Such programs would contribute to a comprehensive treatment that could improve the QOL of patients and their families. It is of interest to determine if a program that stimulates various processes of linguistic functioning is able to produce short and long-term changes (maintenance or improvement) not only at the linguistic functioning level, but also in the QOL and ADLs of the patient, while also improving the family environment. We hypothesize that, through the use of such a program, performance in language processing, general cognition, and socio-emotional areas would improve and that this improvement would be temporarily stable. In order to determine if speech therapy has the potential to positively impact the linguistic performance and the non-linguistic aspects in a patient with PNFA, an intervention program was developed that took into account the linguistic processing model of Levelt, Roeloft \& Meyer (1999), which proposes the interaction and independence of various linguistic subsystems, with expressive language arising from the connection between modules that store specific language information. Thus, a program that combined stimulation strategies related to different components for language processing (phonological, lexical, and syntactic) was elaborated. This 12-month speech therapy program was administered to a patient with PNFA to determine whether this kind of program would improve the patient's language processing, general cognition, neuropsychiatric symptoms (NPS), QOL and ADLs and would also benefit his family.

\section{METHOD}

\section{Participant}

$\mathrm{JM}$ is an 84-year-old, right-handed, male patient who has worked as a merchandiser. He has 12 years of schooling; his first and only language is Spanish. In 2006, JM complained of increasing word-finding difficulties, which evolved into non-fluent discourse. In 2011, JM attended the National Institute of Neurology and Neurosurgery "Manuel Velasco Suárez" (NINN) in Mexico City where exploration was initiated and the necessary studies were performed to determine his general medical condition. In February 2011, magnetic resonance imaging showed reduced cortical and subcortical cerebral and cerebellar volume; the cortical atrophy was predominantly left posterior fronto-insular region. Neurological status was normal. JM's language continued to worsen; in May 2011, JM was diagnosed with PNFA by the clinicians of the Laboratory of Dementia at NINN, following the criteria proposed by Gorno-Tempini et al. (2011).

JM started pharmacological treatment, consisting of citalopram and memantine (20 $\mathrm{mg}$ each per day). This treatment was continued during the one-year course of the speech therapy that he received at the Dementia Clinic (NINN).

\section{Design}

At NINN, over a 12-month period (October 2011 to November 2012), JM received weekly speech therapy from a neuropsychologist (PAAC). This therapy stimulated phonological, lexical, and syntactic processing and was used in conjunction with daily homework. Examination of the therapy effects was documented by applying a single-subject pre-post test design. Written informed patient consent was obtained. The protocol adheres to the Declaration of Helsinki (2008) and the regulations of the General Clinical Research Health Law of Mexico (1983). The Bioethics Committee of the NINN evaluated and accepted this clinical research protocol.

\section{Assessment}

A battery of tests was administered to JM, which assessed the patient's language and general cognitive functioning, NPS, QOL, and ADLs. The emotional state, QOL, and 
burden of the primary caregiver (JM's daughter) were also assessed through the application of three scales. The same instruments (see Materials section) were used at three stages: pre-intervention assessment (basal: October 2011); at six months of intervention (intermediate: April 2012); and after receiving twelve months of therapy (final: November 2012). Implementation and assessment of the speech therapy were conducted by the first author of this paper (PAAC).

\section{Materials}

The neuropsychological assessment battery applied covered general cognitive functioning, with emphasis on the following measures:

General cognitive functioning: Mini-Mental State Examination, MMSE (Folstein, Folstein \& McHugh, 1975); Neuropsychological Integrated Exploration Program "Test Barcelona". Abbreviated Version (Villa, 2006); Informant Questionnaire on Cognitive Decline in the Elderly and IQCODE (Jorm \& Korten, 1988; Morales et al., 1995).

Verbal learning: Auditory Verbal Learning Test, "Test Barcelona" Alfa Version (Peña-Casanova, 2005).

Verbal comprehension: Token Test (De Renzi \& Faglioni, 1978).

Visuo-spatial memory: Rey-Osterrieth Complex Figure Test (Cortés, Galindo \& Salvador, 1996; Rey, 2003).

Executive functioning: Trail Making Test (Partington \& Leiter, 1949); Stroop Color and Word Test (Golden, 1976).

Patient neuropsychiatric symptoms: Neuropsychiatric Inventory Questionnaire, NPI-Q (Cummings et al., 1994); Yesavage Geriatric Depression Scale (Yesavage et al., 1982; Baker \& Espino, 1997) and Beck Anxiety Inventory (Beck et al., 1988; Robles et al., 2001).

Patient functionality and QOL: Barthel Scale (Collin et al., 1988); Pfeffer functional activities questionnaire (PFAQ; Pfeffer et al., 1984); Quality of life for the person with dementia questionnaire (DEMQOL) (Smith et al., 2007) and Quality of Life Questionnaire (DEMQOL-answered by the patient's family) (Smith et al., 2007).

Emotional state of the patient's primary caregiver: Self-reporting questionnaire (SRQ) (Harding, et al., 1980; Mari \& Williams, 1985).

Quality of life and patient's primary caregiver and overload: The World Health Organization Quality of Life Scale (WHOQOL-BREF) (The WHOQOL Group, 1998) and Zarit Caregiver burden scale (Zarit, Reever \& BachPeterson, 1980).

For the implementation of the neuropsychological test battery, three sessions of 60 minutes each, one per week, were required in each of the three instances of assess- ment. The questionnaires were answered by the patient at his residence; the same was true for the questionnaires answere by the primary caregiver. Questionnaires were returned by JM and his family in the second session of each of the three instances of evaluation.

\section{Intervention}

Based on the pre-intervention testing (see Results section), a program was designed for working on JM's language deficits, structuring an intervention that combined exercises to stimulate phonological, lexical and syntactic processing (oral and writing). Writing exercises were included because of the benefit reported in patients (Rodríguez \& Baquero, 2011). In a briefing session with JM and his family before the start of the intervention, the characteristics of PNFA, its causes, course, and prognosis were explained to them; the treatment goals and the importance of family support in the process were also discussed. In this session, JM, his family, and the speech therapist (PAAC) selected four topics (food, home, body and animals) that all agreed were the most important to JM's ADLs; for each of these topics, a list consisting of 20 stimuli that would exercise lexical, phonological and syntactic stimulation was developed. To structure the sentences in each list, four verbs (want, eat, take and give) were selected, since according to JM and his family, these were the most frequently used.

Over a 12-month period, in addition to attending 50 individual sessions (60 min. each) with PAAC, which were held at the Laboratory of Dementia, JM also did daily homework, which consisted of repeating the exercises performed at the clinic. In the first stage (months 1-6), the first 25 sessions consisted of articulation exercises (three sessions), phonological stimulation (six sessions), lexical stimulation (visual and verbal stimulus: eight sessions), and syntactic processing (eight sessions). In the second stage (months 7-12), JM continued with the same sequence of exercises, but the difficulty of the tasks was gradually increased. The sequence of sessions and some examples of the tasks performed are described below.

\section{Strengthening of pulmonary ventilation}

Every session started with ten minutes of exercises to strengthen pulmonary ventilation; for example, the prolonged emission of vowel sounds with exaggerated oral-facial movements.

\section{Stimulation of articulatory release}

In all the sessions, exercises focused on improving articulation were performed; strategies to release automated forms of discourse were used. JM was asked to produce 
automated information (numbers, days of the week, months of the year, songs), reciting sequences in ascending and descending order, changing the rhythm and speed, and combining the visual and verbal stimuli.

\section{Phonological stimulation}

Strategies consisted in sound analysis of the elements that compose each word, allowing rehabilitation of the conscious relationship within the word and its rhythmicmelodic structure. In every session, after the strengthening pulmonary ventilation exercises, JM carried out articulation fluency exercises for ten minutes. The phonological exercises consisted of the following: pronunciation of each phoneme, either in isolation or within a word; repetition tasks; reading aloud; understanding of rhymes; verification of the number of syllables; phoneme identification at the beginning or end of a word; or phonological selection tasks. Speaking and writing exercises were combined.

\section{Lexical stimulation}

When lexical stimulation started, the sessions were divided as follows: strengthening pulmonary ventilation (5 min.), articulation fluency exercises (10 min.), phonological exercises (10 min.) and stimulation of lexical analysis (35 min.). For the lexical analysis, picture-naming tasks were applied, in which JM, working with visual material, named (orally and in writing) and described each stimulus presented.

\section{Syntactic stimulation}

Following the same session structure as that of the lexical stimulation, after strengthening pulmonary ventilation (5 min.), articulation fluency exercises (5 min.) and phonological exercises (5 min.), each session of syntactic tasks lasted 45 minutes. Examples of these exercises are the following: construction of sentences based on the combination of worked stimulus and change of gender, number and tense of the structural elements. Visual and verbal support was always provided by the therapist. These strategies aimed to improve the patient's structural analysis of sentences and speech, thereby enabling recovery and the relearning of grammatical and syntactical elements altered by the progress of the disease.

\section{RESULTS}

\section{Pre-intervention assessment}

The basal assessment revealed that the following mental functions of the patient were preserved: orientation; selective attention for visual material; verbal and visual memory; learning; ideational praxis; and visuo-spatial gnosis. Other mental functions, such as selective attention for verbal material and ideo-motor praxis, showed slight alterations, while sustained attention showed a moderate deficit. In language processing, verbal naming, verbal and text comprehension, and semantic fluency were preserved. However, significant alterations were detected in prosody, repetition, oral praxis, fluency, and content information; phonemic fluency was diminished; reading aloud and writing to dictation of non-words were impaired; syntactic processing was slightly altered; and phonemic paraphasias were frequent (Fig. 1 and Table 1). JM's scales showed good QOL, a slight deterioration in ADLs (due to language deficits), moderate depression, and low anxiety (Table 1). From the questionnaire completed by the primary caregiver (Table 2), some characteristics of burden, but good QOL, were found (Table 2).

\section{Post-intervention assessment}

Comparison of the pre- and post-intervention neuropsychological assessments and scores, summarized in Figure 1 and Tables 1 and 2, suggests that JM's general cognitive abilities before the onset of language therapy were in the average and high ranges. Maintenance of performance was observed for some cognitive processes, such as orientation at the personal, place, and time levels; selective attention for visual and verbal material; divided attention; verbal and visual naming; writing; semantic fluency; ideational praxis; postural imitation; short-term verbal memory; arithmetic ability; and abstraction. There was a slight improvement in the rhythm, prosody, fluency, and content of spontaneous speech, so oral-phonatory praxis had been enhanced after speech therapy. JM was able to give more extensive explanations, but still had little fluency in his speech; no phonetic paraphasias were produced at the end of therapy. Phonological fluency per minute improved from seven to ten elements. Reading aloud pseudo-words designed for the Spanish speaker improved from four to six correct elements, and his processing speed also increased. Repetition, comprehension, writing, dictation, and working memory as ideo-motor praxis were improved at the end of the therapy. Although a decline was observed in semantic fluency, complex verbal comprehension and visual memory, these scores remained within the average range of performance for his age and educational level (Fig. 1).

Over the study period, the patient maintained not only his MMSE scores, but also his verbal comprehension and visuo-spatial memory level of performance. 


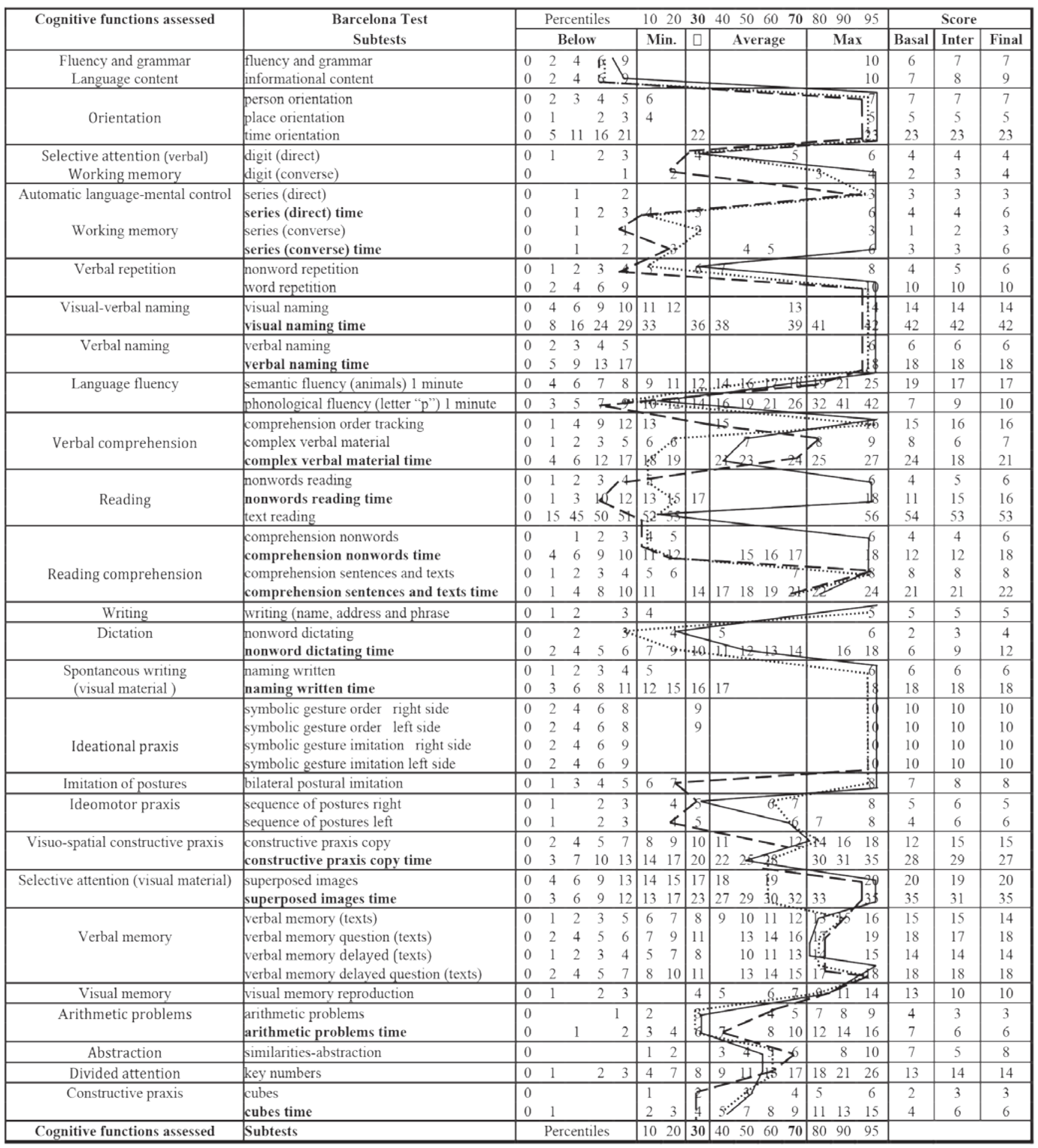

Figure 1. Performance profile of the 84-year-old male patient with progressive nonfluent aphasia in Neuropsychological Integrated Exploration Program "Test Barcelona”. Abbreviated Version".

Pre-intervention evaluation:

(inter, Apr. 2012) and

(basal, Oct. 2011); post-intervention evaluations:

${ }^{a}$ Villa, 2006.

(final, Nov. 2012). 
There were improvements in cognitive inhibition ability, decision-making and managing real-world interference (Stroop Test), with some deterioration in verbal learning, task switching, visual search speed and mental flexibility (Trail Making Test) (Table 1).

Table 1.

Neuropsychological assessment of the 84-year-old male patient with progressive nonfluent aphasia

\begin{tabular}{|c|c|c|c|c|c|c|}
\hline \multirow{3}{*}{ Test } & \multicolumn{6}{|c|}{ Test scores } \\
\hline & Expected & \multicolumn{2}{|c|}{ Pre-intervention } & \multirow[b]{2}{*}{$\begin{array}{c}\text { Inter } \\
\text { April } 2012 \\
\end{array}$} & \multicolumn{2}{|c|}{ Post intervention } \\
\hline & $\begin{array}{l}\text { (based on age and } \\
\text { educational level) }\end{array}$ & \multicolumn{2}{|c|}{$\begin{array}{c}\text { Basal } \\
\text { October } 2011\end{array}$} & & \multicolumn{2}{|c|}{$\begin{array}{c}\text { Final } \\
\text { November } 2012\end{array}$} \\
\hline $\mathrm{MMSE}^{\mathrm{a}}$ & $\geq 23$ & & 26 & 27 & & 6 \\
\hline Token Test ${ }^{\mathrm{b}}$ & $\geq 29$ & & 32 & 34.5 & & 2 \\
\hline \multicolumn{7}{|c|}{ Rey-OsterriethComplex Figure } \\
\hline \multicolumn{7}{|l|}{ Test $^{\mathrm{c}}$} \\
\hline copy & $33( \pm 5)$ & & 30 & 30 & & 5 \\
\hline short-term memory & $10.3( \pm 4.9)$ & & 6 & 16 & & 0 \\
\hline long-term memory & $17( \pm 9)$ & & 11 & 19 & & 8 \\
\hline \multicolumn{7}{|c|}{ Auditory Verbal Learning Test ${ }^{d}$} \\
\hline Stroop Test ${ }^{\mathrm{e}}$ & $\geq 55 \%$ & & $5 \%$ & $76 \%$ & & $\%$ \\
\hline word & $96( \pm 14)$ & & 47 & 76 & & 8 \\
\hline color & $54( \pm 13)$ & & 40 & 55 & & 8 \\
\hline word-color & $34( \pm 9)$ & & 32 & 26 & & 1 \\
\hline \multirow[t]{6}{*}{ Trail Making Test ${ }^{\mathrm{f}}$} & & Part A & Part B & Part A Part B & Part A & Part B \\
\hline & & $111^{\prime \prime}$ & $836^{\prime \prime}$ & B & $114^{\prime \prime}$ & Failedg \\
\hline & & 0 error & 4 errors & $101^{\prime \prime}$ & 0 error & \\
\hline & & & & $841^{\prime \prime}$ & & \\
\hline & & & & 0 error & & \\
\hline & & & & 3 errors & & \\
\hline
\end{tabular}

a MMSE: Mini-Mental State Examination (Folstein, Folstein \& McHugh, 1975);

b De Renzi \& Faglioni, 1978;

c Rey, 2003;

d "Test Barcelona" Alfa Version (Peña-Casanova, 2005);

e Golden, 1976);

f Partington \& Leiter, 1949;

g Failed: The patient could not complete the test without breaking one of the test's rules.
After six and twelve months of therapy, JM's family reported maintenance and even improvement of cognitive functioning (IQCODE), preserved ADLs (Barthel scale and PFAQ), no presence of neuropsychiatric symptoms, and good QOL. No burden was reported, but there was a decrease in the final Zarit score. JM reported no depression, low anxiety, and good QOL (Table 2). 
$\underline{\text { Table } 2}$

Neuropsychiatric, QoL and ADLs assessments of the 84-year-old male patient with progressive nonfluent aphasia

\begin{tabular}{|c|c|c|c|c|c|c|}
\hline \multirow{4}{*}{ Scales } & \multicolumn{6}{|c|}{ Test results } \\
\hline & \multirow{2}{*}{\multicolumn{2}{|c|}{$\frac{\text { Pre intervention }}{\text { Basal (Oct 2011) }}$}} & \multicolumn{4}{|c|}{ Post intervention } \\
\hline & & & \multicolumn{2}{|c|}{ Inter (Apr 2012) } & \multicolumn{2}{|c|}{ Final (Nov 2012) } \\
\hline & Score & Interpretation & Score & Interpretation & Score & Interpretation \\
\hline IQCODE $^{\mathrm{a}}$ & 3.7 & $\begin{array}{c}\text { Cognitive } \\
\text { deterioration }\end{array}$ & 1.61 & No deterioration & 1 & No deterioration \\
\hline $\mathrm{GDS}^{\mathrm{b}}$ & 12 & Depressed & 8 & No depression & 5 & No depression \\
\hline $\mathrm{BAI}^{\mathrm{c}}$ & 11 & Low anxiety & 5 & Low anxiety & 8 & Low anxiety \\
\hline Barthel Scale ${ }^{\mathrm{d}}$ & 100 & Autonomous & 100 & Autonomous & 100 & Autonomous \\
\hline $\mathrm{PFAQ}^{\mathrm{e}}$ & 1 & Functional & 1 & Functional & 2 & Functional \\
\hline $\mathrm{NPI}^{\mathrm{f}}$ & 1 & Depression & 0 & No symptoms & 0 & No symptoms \\
\hline DEMQOL $^{g}$ & Good & & Good & & Good & \\
\hline DEMQOL-FAM ${ }^{\mathrm{h}}$ & Mild & & Good & & Good & \\
\hline WHOQOL-BREF ${ }^{\mathrm{i}}$ & Good & & Good & & Good & \\
\hline SRQ $^{\mathrm{j}}$ & 0 & No symptoms & 0 & No symptoms & 0 & No symptoms \\
\hline Zarit $^{\mathrm{k}}$ & 31 & No burden & 21 & No burden & 11 & No burden \\
\hline
\end{tabular}

a Informant Questionnaire on Cognitive Decline in the Elderly (Jorm \& Korten, 1988; Morales et al., 1995);

b Geriatric Depression Scale (Yesavage et al., 1982; Baker \& Espino, 1997);

c Beck Anxiety Inventory (Beck et al., 1988; Robles et al., 2001);

d Collin et al., 1988;

e Pfeffer Functional Activities Questionnaire (Pfeffer et al., 1984);

${ }^{\mathrm{f}}$ Neuropsychiatric Inventory (Cummings et al., 1994);

g Quality of life for the person with dementia questionnaire (Smith et al., 2007);

${ }^{\text {h }}$ Quality of Life Questionnaire answered by the patient's family (Smith et al., 2007);

i World Health Organization Quality of Life Scale (The WHOQOL Group, 1998);

j Self-reporting questionnaire (Harding, et al., 1980; Mari \& Williams, 1985);

${ }^{\mathrm{k}}$ Caregiver burden scale (Zarit, Reever \& Bach-Peterson, 1980).

In summary, while some aspects of cognitive functioning remained intact, especially in orientation, verbal naming, praxis and memory, there was a slight improvement in verbal fluency and rhythm, but a gradual decline in arithmetic problem solving. Informally, members of JM's family reported that he was participating more in social life and losing his fear of starting a conversation with relatives or strangers; they associated this behavior to better QOL for JM and family members.

\section{DISCUSSION}

Cognitive rehabilitation and speech therapy were initially developed to treat patients with non-progressive brain diseases; however, they can also be applied to people with progressive neurodegenerative diseases such as FTD and other dementias. In such cases, as the disease progresses, the approach and goals must be changed and adapted because priorities will be different for both the patient and family members (Heredia et al., 2009, Wilson, 2008). For neurodegenerative diseases, the effectiveness of the intervention would also have to be assessed differently, because the cognitive performance of the patient is not stable, and so the benefits are related to a delay in, or slowing of, deterioration.

The present study shows that a program of speech therapy, specifically adapted to the patient diagnosed with PNFA can improve articulation, repetition, fluency, and expressive language content, and also has a positive impact on other cognitive processes of the patient. It was demonstrated that this stimulation program slowed cognitive decline in the patient, because with twelve months of therapy, maintenance and improvements were observed in his performance profile which, considering the rapid progression of this disease, was a successful treatment of PNFA. This was the first part of the intervention; there has been a follow-up of the patient in order to determine his levels of language skills and cognitive function over time; 
and modifications will be made according to the patient's performance (environmental modifications, including tasks that stimulate memory, attention and executive functioning).

These results are in agreement with studies that have shown that patients diagnosed with PNFA can benefit from speech therapy; due to intervention, a less severe decline in language functioning was demonstrated (Farrajota et al., 2012; Jokel et al., 2009; Koenig-Bruhin et al., 2005; Laurence et al., 2002; Louis et al., 2001; McNeil et al., 1995; Rapp \& Glucroft, 2009; Schneider et al., 1996). However, the present research differs from these other studies, in that the treatment program is aimed at stimulating different processes of expressive language functioning in a patient with PNFA. This intervention program has showed that this kind of therapy could have a positive effect not only on language and other cognitive processes (memory, attention, praxis), but also on the patient's QOL and ADLs, as has been suggested in previous studies (Clare et al., 2003; Rogers, King \& Alarcón, 2000; Wong et al., 2009).

Therapy began with exercises involving the repetition of series of automatic language information and phonological segments, including phonological awareness, all of which may strengthen the connection and retrieval of phonological representations, information that is essential for communication of semantic and syntactic content (Levelt, Roeloft \& Meyer, 1999). When some improvements in fluency, rhythm, melody of language, and finally articulation, due to the repetition of motor sequences that promote better oral production had been attained, exercises to stimulate naming and syntactic processes were introduced. This resulted in a slight increase in the content of the patient's speech. The overall performance profile of the patient after twelve months of receiving speech therapy showed maintenance and improvement of some cognitive processes, apart from language, and only slight declines. Because the generation of fluent speech requires planning in order to convey the intentions of the speaker, language processing involves a large number of cortical and subcortical structures. This implies an appropriate selection, ordering, and formation of words, as well as muscle movements (Levelt, Roeloft \& Meyer, 1999). Therefore, an explanation of the success of the patient's treatment may be that performing exercises that stimulate language can activate various cortical regions.

For example, functional neuroimaging studies have demonstrated that the frontal region shows activation during phonological processing tasks, repetition, semantic and lexical decisions; it is also involved with aspects of response selection, monitoring, conflict resolution and decisionmaking related to the execution of movements (Careeiras et al., 2006; Gernsbacher \& Kaschak, 2003; Trenblay \&
Gracco, 2009). The temporal lobe is frequently involved in language syntax processes and the decoding and recovery of complex linguistic long-term memory materials (Mandonnet et al., 2007). The left posterior parietal cortex could be part of the temporo-parietal-frontal network, a system that acts as an interface between auditory and articulatory processes (Ackermann \& Rieker, 2004; Loevenbruck et al., 2005). For the subcortical structures, evidence indicates that the basal ganglia are involved in the generation of complex language movements (Murdoch, 2001) and the insula in sensory mechanisms of language production control (Ackermann \& Rieker, 2004; Loevenbruck, 2005) and affective-prosodic processing (Ackermann \& Rieker, 2004).

Here, the constant stimulation of these regions through speech therapy exercises also seemed to benefit memory, frequently deteriorated in older adults (Ochoa, Aragón $\&$ Caicedo, 2005); attention and praxis processing associated with the neuroanatomical structures mentioned above. Thus, the combination of speech therapy strategies used in this study may have had the capacity to stimulate a wider range of impaired and/or preserved cognitive functions of the patient, thereby allowing maintenance and/or stabilization of the patient's general cognitive functioning. Based on these findings, an assessment of general cognitive functioning of patients with PNFA is necessary to understand the potential benefits derived from any intervention proposed.

An important aspect of the specific speech therapy program provided in the current study was the adaptation of material for use with this Spanish-speaking patient (in effect, culturally related sounds and material), as this may have had a positive influence on the results obtained. Also essential was family involvement in the daily conducting of the recommended exercises; such involvement is critical for any speech therapy in the short and long term. From the scores for the scales of QOL, ADLs, neuropsychiatric symptoms, and burden, valuable information was obtained concerning non-cognitive aspects of the intervention over the year.

It is important to note the improvement in the mood of the patient, who reported absence of depression and less anxiety after the intervention. Therefore, this type of intervention programs can have a positive impact and improve neuropsychiatric symptoms (measured by improving communication directly and indirectly through the caregiver); these indicators can be related to the quality of life of patients and undoubtedly have a positive effect on cognitive functioning (Clare et al., 2003; Rogers, King \& Alarcón, 2000; Wong et al., 2009).

In this study, the use of a test battery to assess non-cognitive aspects of neurodegenerative diseases provided us 
with a comprehensive knowledge of the patient's state. Such information should be taken into account in the intervention of neurodegenerative diseases.

One limitation of the present work is its single-case design, which makes it impossible to generalize the results to other PNFA patients; another limitation that may bias or influence the results is the patient's educational level, as it may be associated with cognitive reserve, a factor that plays an important role in preventing, or slowing, the neurodegenerative process (Stern, 2002). For future research in this area, the implementation of such a speech therapy program with a group of patients having different educational levels is worth considering in order to determine whether such a program would be beneficial to a wider range of PNFA patients. This, in addition to the use of functional magnetic resonance imaging or other functional neuroimaging studies (such as single photon emission computed tomography (SPECT) or positron emission tomography (PET)), can be used to identify possible changes in brain activation patterns over time resulting from speech therapy.

As a conclusion, the characteristics of the interventions described in the present study showed the need and importance of designing and implementing systematic speech therapies that encourage expressive language performance for patients with PNFA. Also important is the dissemination of these successful strategies among members of the research community, physicians and speech therapists in order to benefit more patients. Such therapies, by providing an adapted intervention to the progressive language deficits in patients suffering from PNFA, could have a positive impact on other cognitive and socio-emotional processes, thereby improving the ADLs of patients and the QOL both of patients and of their families.

\section{REFERENCES}

Ackermann, H. \& Riecker, A. (2004) The Contribution of the Insula to Motor Aspects of Speech Production: A Review and a Hypothesis. Brain and Language, 89 (2): 320-328. doi: 10.1016/S0093-934X(03)00347-X

Baker, M. \& Espino, D. V. (1997) A Spanish Version of the Geriatric Depression Scale in Mexican-American Elders. International Journal of Geriatric Psychiatry, 12: 21-25. doi: 10.1002/(SICI)1099-1166(199701)

Beck, T., Brown, G., Epstein, N. \& Steer, A. (1988) An Inventory for Measuring Clinical Anxiety: Psychometric Properties. Journal of Consulting and Clinical Psychology, 56: 893-897. doi: 10.1037/0022-006X.56.6.893

Berndt, R, Mitchum, C. \& Haending, A. (1996) Comprehension or Reversible Sentences In "Agrammatism": A Meta-Analysis. Cognition, 58: 289-308.
Boeve, B. (2003) Diagnosis and Management of the Non-Alzheimer Dementias. In J. H. Noseworthy (Ed.), Neurological Therapeutics: Principles and Practice (pp. 2826-2854). New York: Martin Dunitz.

Carreiras, M., Mechelli, A. \& Price, C.J. (2006) Effect of Word and Syllable Frequency on Activation During Lexical Decision and Reading Aloud. Human Brain Mapping, 27: 963-972. doi: $10.1002 / \mathrm{hbm} .20236$.

Clare, L., Wilson, B.A., Carter, G. \& Hodges, J.R. (2003). Cognitive Rehabilitation as a Component of Early Intervention in Dementia: A Single Case Study. Aging \& Mental Health, 7:15-21. doi: 10.1080/1360786021000045854.

Clark, D., Charuvastra, A., Miller, B., Shapira, J. \& Mendez, M. (2005) Fluent Versus Non-Fluent Primary Progressive Aphasia: A Comparison of Clinical and Functional Neuroimaging Features. Brain and Language, 94: 54-60. doi: 10.1016/j. band1.2004.11.007.

Collin, C., Wade, D.T., Davies, S. \& Horne, V. (1988) The Barthel ADL Index: A Reliability Study. International Disability Studies, 10: 61-63. doi: 10.3109/09638288809164103.

Cortés, J., Galindo, G. \& Salvador, J. (1996) La figura compleja de Rey: Propiedades psicométricas. Salud Mental, 19(3): 42-48. From http://www.inprf-cd.org.mx/pdf/sm2002/sm 200217.pdf

Cummings, J., Mega, M., Gray, K., Rosenberg-Thompson, S., Carusi, D. \& Gornbein, J. (1994) The Neuropsychiatric Inventory: Comprehensive Assessment of Psychopathology in Dementia. Neurology, 44: 2308-2314. doi: 10.1212/ WNL.44.12.2308

De Renzi, R. \& Faglioni, P. (1978) Normative Data and Screening Power of a Shortened Version of the Token Test. Cortex, 14(1): 41-49. doi: 10.1016/S0010-9452(78)80006-9

Declaration of Helsinki (2008). World Medical Association. Available from: http://www.wma.net/en/30publications/ 10policies/b3/ [accessed on 22 January 2014].

Farrajota, L., Maruta, C., Maroco, J., Martins, I., Guerreiro, M. \& De Mendonça, A. (2012) Speech Therapy in Primary Progressive Aphasia: A Pilot Study. Dementia and Geriatric Cognitive Disorders Extra, 2: 321-331. doi: 10.1159/000341602

Folstein, M., Folstein, S. \& McHugh, P. (1975) "Mini-mental state". A Practical Method for Grading the Cognitive State of Patients for the Clinician. Journal of Psychiatric Research, 12(3): 189-98.

Friederici, A. \& Kotz, S. (2003) The Brain Basis of Syntactic Processes: Functional Imaging and Lesion Studies. NeuroImage, 20: S8-S17. doi: 10.1016/j.neuroimage.2003.09.003

Gernsbacher, M. \& Kaschak, M. (2003) Neuroimaging Studies of Language Production and Comprehension. Ann. Rev. Psychology, 54:91-114. doi: 10.1146/annurev.psych. 54.101601.145128

General Clinical Research Health Law of Mexico (1983). Published on February 7, 1984 in the Official Journal of the Federation of Health Regulatory Law, the third paragraph of Article 4o. of the Constitution of the United Mexican States, starting in force on 1. July of the same year. 
Golden, C. (1976) Identification of Brain Disorders by the Stroop Color-Word Test. Journal of Clinical Psychology, 32: 654-658. doi: 10.1002/1097-4679(197607)32:3<654::AIDJCLP2270320336>3.0.CO;2-Z

Gorno-Tempini, M., Murray, R., Rankin, K., Weiner, M. \& Miller, B. (2004) Clinical, Cognitive and Anatomical Evolution from Nonfluent Progressive Aphasia to Corticobasal Syndrome: A Case Report. Neurocase, 10: 426-436. doi: 10.1080/13554790490894011

Gorno-Tempini, M., Ogar, J. M., Brambati, S. M., Wang, P., Jeong, J. H., Rankin, K. P., Dronkers, N. F. (2006) Anatomical Correlates of Early Mutism in Progressive Nonfluent Aphasia. Neurology, 67: 1849-1851. doi: 10.1212/01. wnl.0000237038.55627.5b

Gorno-Tempini, M, Hillis, A., Weintraub, S., Kertesz, A., Mendez, M., Cappa, S., Ogar, J., Rohrer, J., Black, S., Boeve, F., Manes, F., Dronkers, N., Vandenberghe, R., Rascovsky, K., Patterson, K., Miller, B., Knopman, D., Hodges, J., Mesulam, M. \& Grossman, M. (2011) Classification of Primary Progressive Aphasia and its Variants. Neurology, 76(11): 1006-1014. doi:10.1212/WNL.0b013e31821103e6

Graham, N., Patterson, K. \& Hodges, J. (2004) When More Yields Less: Speaking and Writing Deficits in Nonfluent Progressive Aphasia. Neurocase, 10: 141-155. doi: 10.1080/13554790409609945

Graham, N., Patterson, K., Bak, T. \& Hodges, J. (2003) Language Function and Dysfunction in Corticobasal Degeneration. Neurology, 61: 493-499. doi: 10.1212/01. WNL.0000081230.09863.ED

Greenwald, M., Raymer, A., Richardson, M. \& Rothi, L. (1995) Contrasting Treatment for Severe Impairment or Picture Naming. Neuropsychological Rehabilitation, 5: 17-49.

Harding, T., De Arango, M., Baltazar, J., Climent, C., Ibrahim, H., Ladrido-Ignacio, L., Murthy, R. \& Wig, N. (1980) Mental Disorders in Primary Health Care: A Study of Their Frequency and Diagnosis in Four Developing Countries. Psychological Medicine, 10: 231-241. doi:10.1017/S0033291700043993

Heredia, C. G., Sage, K., Ralph, M. \& Berthier, M. (2009) Relearning and retention of verbal labels in a case of semantic dementia. Aphasiology, 22: 192-209. doi: 10.1080/ 02687030801942999

Hodges, J., Patterson, K., Ward, R., Garrard, P., Bak, T., Perry, R. \& Gregory, C. (1999) The Differentiation of Semantic Dementia and Frontal Lobe Dementia (Temporal and Frontal Variants of Frontotemporal Dementia) from Early Alzheimer's Disease: A Comparative Neuropsychological Study. Neuropsychology, 13: 31-40. doi: 10.1037/0894-4105.13.1.31

Hodges, J., Davies, R., Xuereb, J., Kril, J. \& Halliday, G. (2003) Survival in Frontotemporal Dementia. Neurology, 61:349-54. doi: 10.1212/01.WNL.0000078928.20107.52

Hodges, J., Bozeat, S., Lambon Ralph, M., Patterson, K. \& Spatt, J. (2000) The Role of Conceptual Knowledge in Object Use: Evidence from Semantic Dementia. Brain, 123(9): 1913-1925. doi: 10.1093/brain/123.9.1913
Jorm, A. \& Korten, A. (1988) Assessment of Cognitive Decline in the Elderly by Informant Interview. British Journal of Psychiatry, 152: 309-213. doi:10.1192/bjp.152.2.209

Jokel, R., Cupit, J., Rochon, E. \& Leonard, C. (2009) Relearning Lost Vocabulary in Nonfluent Progressive Aphasia with MossTalk Words. Aphasiology, 23(2): 175-191. doi:10.1080/02687030801943005

Kiran, S. \& Thompson, C. (2002) The Role of Semantic Complexity in Treatment of Naming Deficits: Training Semantic Categories in Fluent Aphasia by Controlling Exemplar Typicality. Journal of Speech-Language-Hearing Research, 46: 608-622.

Koenig-Bruhin, M., Studer-Eichenberger, F., Donati, F., Zwahlen, J. \& Höhl, B. (2005) Language Therapy in Fluent Primary Progressive Aphasia. A Single Case Study. Brain and Language, 95: 135-136. doi: 10.1016/j.bandl.2005.07.076

Laurence, F., Manning, M. \& Croot, K. (2002) Impairment-Based Interventions in Primary Progressive Aphasia: Theoretical and Clinical Issues. Paper Presented at the 10th International Aphasia Rehabilitation Conference: Past, Present and Future, Brisbane, Australia.

Levelt, W., Roeloft, A. \& Meyer, A. (1999) A Theory of Lexical Access in Speech Production. Behavioral and Brain Sciences, 22: 1-75.

Loevenbruck, H., Baciu, M., Segebarth, C. \& Abry C. (2005) The Left Inferior Frontal Gyrus under Focus: An Fmri Study of the Production of Deixis via Syntactic Extraction and Prosodic Focus. Journal of Neurolinguistics, 18(3): 237-258. doi: 10.1016/j.jneuroling.2004.12.002

Louis, M., Espesser, R., Rey, V., Daffaure, V., Di Cristo, A. \& Habib, M. (2001) Intensive Training of Phonological Skills in Progressive Aphasia: A Model of Brain Plasticity in Neurodegenerative Disease. Brain and Cognition, 46(1-2): 197-201. doi: 10.1016/S0278-2626(01)80065-8

Mandonnet, E., Nouet, A., Gatignol, P., Capelle, L. \& Duffau, H. (2007) Does the Left Inferior Longitudinal Fasciculus Play a Role in Language? A Brain Stimulation Study. Brain, 130: 623-629. doi:10.1093/brain/awl361

Mari, J. \& Williams, P. (1985) A Comparison of the Validity of Two Psychiatric Screening Questionnaires (GHQ-12 and SRQ-20) in Brazil, using Relative Operating Characteristic (ROC) Analysis. Psychological Medicine, 15: 651-659. doi:10.1192/bjp.148.1.23

McNeil, M. R., Small, S. L., Masterson, R. J. \& Tepanta, R. D. (1995) Behavioural and Pharmacological Treatment of Lexical-Semantic Deficits in a Single Patient with Primary Progressive Aphasia. American Journal of Speech-Language Pathology, 4: 76-93. doi: doi:10.1044/1058-0360.0404.76

Mesulam, M. (2003) Primary Progressive Aphasia-A LanguageBased Dementia. New England Journal of Medicine, 349: 1535-1542. doi:10.1056/NEJMra022435

Mesulam, M. M., Grossman, M., Hillis, A., Kertesz, A. \& Weintraub, S. (2003) The Core And Halo of Primary Progressive 
Aphasia and Semantic Dementia. Annals of Neurology, 54: S11-S14. doi: 10.1002/ana.10569

Mioshi, E., Bristow, M., Cook, R. \& Hodges, J. R. (2009) Factors Underlying Caregiver Stress in Frontotemporal Dementia and Alzheimer's Disease. Dementia and Geriatric Cognitive Disorders, 27: 76-81. doi: 10.1159/000193626

Morales, J., González-Montalvo, J., Bermejo, F. \& Del-Ser, T. (1995) The Screening of Mild Dementia with a Shortened Spanish Version of the Informant Questionnaire on Cognitive Decline in the Elderly. Alzheimer Disease and Associated Disorders, 9: 105-111.

Murdoch, B. (2001) Subcortical Brain Mechanism in Speech and Language. Folia Phoniatrica et Logopaedica, 53: 233-251. doi: $10.1159 / 000052679$

Neary, D., Snowden, J., Gustafson, L., Passant, U., Stuss, D., Black, S. \& Freedman, M. (1998) Frontotemporal Lobar Degeneration: A Consensus on Clinical Diagnostic Criteria. Neurology, 51: 1546-1554. doi: 10.1212/WNL.51.6.1546

Nestor, P., Graham, N., Fryer, T., Williams, G., Patterson, K. \& Hodges, J. (2003) Progressive Non-Fluent Aphasia is Associated with Hypometabolism Centred on the Left Anterior Insula. Brain, 126: 2406-2418. doi: 10.1093/ brain/awg240

Partington, J. \& Leiter, R. (1949) Partington's Pathways Test. Psychological Service Center Journal, 1: 11-20. Cited in: Ashendorf, L., Swenson, R. \& Libon, D. (2013) The Boston Process Approach to Neuropsychological Assessment: A Practitioner Guide. Pag. 111-121. New York: Oxford University Press.

Ochoa, S., Aragón, L. \& Caicedo A. (2005). Memoria y metamemoria en adultos mayores: estado de la cuestión. Acta Colombiana de Psicología 14: 19-32.

Pfeffer, R., Kurosaki, T., Chance, J., Filos, S. \& Bates, D. (1984) Use of the Mental Function Index in Older Adults. Reliability, Validity, and Measurement of Change Over Time. American Journal of Epidemiology, 120: 922-35. From http:/aje.oxfordjournals.org/content/120/6/922.full.pdf + html

Peña-Casanova, J. (2005) Normalidad, semiología y patología neuropsicológicas. Programa Integrado de Exploración Neuropsicológica. Test Barcelona Revisado. Barcelona: Masson.

Perry, R. \& Hodges, J. (2000) Differentiating Frontal and Temporal Variant Frontotemporal Dementia from Alzheimer's Disease. Neurology, 54: 2277-2284. doi: 10.1212/WNL. 54.12.2277.

Rapp, B. \& Glucroft, B. (2009) The Benefits and Protective Effects of Behavioural Treatment for Dysgraphia in a Case of Primary Progressive Aphasia. Aphasiology, 22; 236-265. doi: $10.1080 / 02687030801943054$

Raymer, A., Bandy, Adair, J., Schwartz, R., Williamson, D., Gonzalez, L. \& Heilman, K. (2001) Effects of Bromocriptine in a Patient with Crossed Nonfluent Aphasia: A Case Report. Archives of Physical Medicine and Rehabilitation, 82(1): 139-144. doi:10.1053/apmr.2001.18056
Raymer. A. \& Ellsworth, T. (2002) Response to Contrasting Verb Retrieval Treatment. Aphasiology, 16: 1031-1045.

Rey, A. (2003) Test de copia y de reproducción de memoria de figuras geométricas complejas. Madrid: TEA Ediciones, S.A.

Riedijk, M. L., De Vugt, M., Duivenvoorden, H., Niermeijer, M., Van Swieten, J., Verhey, F. \& Tibben, A. (2006) Caregiver Burden, Health-Related Quality of Life and Coping in Dementia Caregivers: A Comparison of Frontotemporal Dementia and Alzheimer's Disease. Dementia and Geriatric Cognitive Disorders 22: 405-412. doi: 10.1159/000095750

Robles, R., Varela, R., Jurado, S. \& Páez, F. (2001) Versión mexicana del Inventario de ansiedad de Beck: Propiedades psicométricas. Revista Mexicana de Psicología, 18: 211-218.

Rodríguez, J. \& Baquero, S. (2001) Escritura en enfermedad de Parkinson (EP): Revisión sistemática de literatura. Acta Colombiana de Psicología, 14 (2): 17-26.

Rogalski, E., Cobia, D., Harrison, T., Wieneke, C., Thompson, C., Weintraub, S. \& Mesulam, M. (2011) Anatomy of Language Impairments in Primary Progressive Aphasia. The Journal of Neuroscience, 31(9): 3344-3350. doi: 10.1523/ JNEUROSCI.5544-10.2011

Rogers, M. A. \& Alarcon, N. B. (1999) Characteristics and Management of Primary Progressive Aphasia. ASHA Special Interest Division Neuropsychology and Neurogenic Speech and Language Disorders, 9(4): 12-26.

Rogers, M., King, J. \& Alarcon, N. (2000) Proactive Management of Primary Progressive Aphasia. In: Beukelman, D., Yorkston, K. \& Reichle, J. (Eds.), Augmentative and Alternative Communication for Adults with Acquired Neurologic Disorders (pp. 305-337). Baltimore: Brookes.

Schneider, S. L., Thompson, C. K. \& Luhring, B. (1996) Effects of Verbal Plus Gestural Matrix Training on Sentence Production in a Patient with Primary Progressive Aphasia. Aphasiology, 10: 297-317. doi: 10.1080/02687039608248414

Smith, S., Lamping, D., Banerjee, S., Harwood, R., Foley, B., Smith, P., Cook, J., Murray, J., Prince, M., Levin, E., Mann, A. \& Knapp, M. (2007) Development of a New Measure of Health-Related Quality of Life for People with Dementia: DEMQOL. Psychological Medicine, 37: 737-746. doi: 10.1017/S0033291706009469

Stern, Y. (2002) What is Cognitive Reserve? Theory and Research Application of the Reserve Concept. Journal of the International Neuropsychological Society, 8 (3): 448-460. doi: http://dx.doi.org/10.1017/S1355617702813248

The WHOQOL Group (1998) Development of the World Health Organization WHOQOL- BREF Quality of Life Assessment. Psychological Medicine, 28(3): 551-558.

Tremblay, P. \& Gracco, V. (2009) Contribution of the Pre-SMA to the Production of Words and Non-Speech Oral Motor Gestures, as Revealed by Repetitive Transcranial Magnetic Stimulation (rTMS). Brain Research, 1268: 112-124. doi: 10.1016/j.brainres.2009.02.076 
Villa, M.A. (2006) Perfiles normales para la utilización del test Barcelona abreviado. Archivos of Neurociencias, 11(1): Deficiency Syndrome: Clinical, Genetic and Therapeutic Aspects. 49-63. From http://www.scielo.org.mx/cgi-bin/wxis.exe/iah/

Wang, D., Pascual, J. \& Yang, H. (2005) GLUT-1 Ann Neurol, 57: $111-118$.

Wilson, B. (2008) Neuropsychological Rehabilitation. Annual Review of Clinical Psychology, 4: 141-62. doi:10.1146/ annurev.clinpsy.4.022007.141212

Wong, S. B. C., Anand, R., Chapman, S. B., Rackley, A. \& Zientz, J. (2009) When Nouns and Verbs Degrade: Facilitating Com- munication in Semantic Dementia. Aphasiology, 22: 286-301. doi: $10.1080 / 02687030801943112$

Yesavage, J., Brink, T., Rose, T., Lum, O., Huang, V., Adey, M. \& Leirer, V. (1982) Development and Validation of a Geriatric Depression Screening Scale: A Preliminary Report. Journal of Psychiatric Research, 17(1): 37-49. doi: 10.1016/0022-3956(82)90033-4

Zarit, S., Reever, K. \& Bach-Peterson, J. (1980) Relatives of the Impaired Elderly: Correlates of Feelings of Burden. The Gerontologist, 20(6): 649-655. 